\title{
Induction of corneal collagen cross-linking in experimental corneal alkali burns in rabbits
}

\section{Indução de ligações covalentes de colágeno em queimaduras corneanas experimentais por álcali em coelhos}

\author{
Marcello Colombo-Barboza ${ }^{1,2,3}$, Guilherme Colombo-Barboza ${ }^{1,2}$, Sergio Felberg ${ }^{2}$, Paulo Elias Corrêa Dantas ${ }^{2}$, Elcio Hideo Sato ${ }^{4}$
}

\begin{abstract}
Objective:To evaluate the effect of riboflavin-ultraviolet-A-induced cross-linking (CXL) following corneal alkali burns in rabbits.

Methods: The right corneas and limbi of ten rabbits were burned using a $1 \mathrm{~N}$ solution of $\mathrm{NaOH}$ and the animals were then divided into two groups: a control group submitted to clinical treatment alone and an experimental group that was treated $1 \mathrm{~h}$ after injury with CXL, followed by the same clinical treatment as administered to the controls. Clinical parameters were evaluated post-injury at 1 , 7,15 , and 30 days by two independent observers. Following this evaluation, the corneas were excised and examined histologically.

Results: There were no statistically significant differences in clinical parameters, such as hyperemia, corneal edema, ciliary injection, limbal ischemia, secretion, corneal neovascularization, symblepharon, or blepharospasm, at any of the time-points evaluated. However, the size of the epithelial defect was significantly smaller in the CXL group $(p<0.05)$ (day 15: $p=0.008$ and day 30: $p=0.008)$ and the extent of the corneal injury (opacity lesion) was also smaller (day 30: $p=0.021$ ). Histopathology showed the presence of collagen bridges linking the collagen fibers in only the CXL group.
\end{abstract}

Conclusions: These results suggest that the use of CXL may improve the prognosis of acute corneal alkali burns.

Keywords: Cross-linking reagents; Riboflavin;Ultraviolet therapy/methods; Cornea/ drug effects; Rabbits; Animal

\section{RESUMO}

Objetivo: Avaliar o efeito de ligações covalentes de colágeno (cross-linking [CXL]) induzidas pelo tratamento com riboflavina e radiação ultravioleta A após queimaduras por álcali em córneas de coelhos.

Métodos: Dez coelhos foram submetidos a queimadura ocular direita abrangendo estruturas da córnea e limbo usando uma solução de $\mathrm{NaOH}$ a $1 \mathrm{~N}$. A seguir, os animais foram divididos em dois grupos: um grupo controle submetido a tratamento clínico pós dano corneano e um grupo experimental que foi tratado com CXL uma hora após o dano, seguido pelo mesmo tratamento clínico administrado aos controles. Os parâmetros clínicos foram avaliados 1, 7, 15 e 30 dias após a lesão, por dois observadores independentes. Na etapa sequinte, foi realizada a excisão e o exame histológico das córneas.

Resultados: Não houve diferenças estatisticamente significantes nos parâmetros clínicos de hiperemia, edema da córnea, injeção ciliar, isquemia límbica, secreção, neovascularização da córnea, simbléfaro ou blefaroespasmo, em qualquer dos momentos da avaliação. Entretanto, o grupo CXL apresentou um defeito epitelial menor $(p<0,05)$ (dia 15: $p=0,008$ e dia 30: $p=0,008$ ) e menor extensão da lesão na córnea (lesão opaca) (dia 30: $p=0,021$ ). O exame histopatológico revelou a presença de pontes de colágeno conectando as fibras de colágeno somente no grupo CXL.

Conclusões: Estes resultados sugerem que o uso de CXL pode melhoraro prognóstico de queimaduras agudas da córnea causadas por alcáli.

Descritores: Reagentes para ligações cruzadas; Riboflavina; Terapia ultravioletal métodos; Córnea/efeito de drogas; Coelhos; Animal

\section{INTRODUCTION}

Eye burns are common and may be caused by various chemical and physical agents including acids, alkalis, high temperatures, and fire ${ }^{(1)}$. They are most generally a consequence of chemical handling accidents and may result in permanent damage to the ocular surface and visual function ${ }^{(1)}$.

Corneal alkali burns are considered an ophthalmologic emergency. Therefore, timely recognition and implementation of the appropriate treatment represent important steps in controlling the progression of early and late complications ${ }^{(2)}$. The literature describes various forms of treatment for corneal alkali burns. These include artificial tears, collagenase inhibitors, therapeutic contact lenses, topical fibronectin, topical vitamin C, topical citrate ${ }^{(2)}$, conjunctival transplantation ${ }^{(1)}$, amniotic membrane patching ${ }^{(3,4)}$, limbal transplantation ${ }^{(5)}$, and autologous serum eye drops ${ }^{(6)}$ as well as treatment of the severe inflammatory processes with topical or systemic corticosteroids.
Chemical burns may lead to devastating complications, including corneal perforation due to the rapid degradation of collagen fibers ${ }^{(1)}$. Recently, riboflavin-ultraviolet-A-induced cross-linking (CXL) was developed as a technique for enhancing collagen cross-linking in the treatment of corneal wounds ${ }^{(7)}$. CXL has been reported to be a safe and effective method for controlling the progression of corneal ectasia ${ }^{(8,9)}$. The procedure stops the melting process of the cornea ${ }^{(10)}$ and has been shown to increase the resistance of porcine corneas by inhibiting enzymatic degradation ${ }^{(11)}$. CXL was previously used in five cases of corneal necrosis following a bacterial infection refractory to clinical treatment ${ }^{(12)}$, and it was demonstrated that this technique constitutes a useful alternative to emergency keratoplasty by increasing corneal resistance against the action of collagenolytic enzymes. Currently, CXL is used to stabilize degenerative corneal disorders such as corneal ectasia (in keratoconus patients and following refractive surgery), where it acts to increase the degree of rigidity of the stromal collagen fibers ${ }^{(13,14)}$.
Submitted for publication: February 28, 2014

Accepted for publication: June 16, 2014

Study conducted at Santa Casa de Misericórdia de São Paulo, São Paulo, SP, Brazil.

Hospital Oftalmológico Visão Laser, Santos, SP, Brazil.

Department of Ophthalmology, Santa Casa de Misericórida de São Paulo, São Paulo, SP, Brazil.

${ }^{3}$ Centro Universitário Lusíada, Santos, SP, Brazil.

${ }^{4}$ Centro Universitário Lusiada, Santos, SP, Brazil.
Department of Ophthalmology and Visual Sciences, Paulista School of Medicine (EPM), Federal University of São Paulo (UNIFESP), São Paulo, SP, Brazil.
Funding: No specific financial support was available for this study.

Disclosure of potential conflicts of interest: None of the authors have any potential conflicts of interest to disclose.

Corresponding author: Marcello Colombo Barboza. Av. Conselheiro Nebias, 355 - Santos, SP 11015-001 - Brazil -E-mail: colombobarbosa@uol.com.br

Research ethics committee: The protocol of this study was approved by the institutional Anima Research Ethics Committee of UNIFESP and the Santa Casa de São Paulo (approval number $1476 / 09)$. 
Considering these aspects, the objective of the present study was to evaluate the effect of CXL in a rabbit model, initiated one hour after a corneal alkali burn.

\section{METHODS}

This was a comparative, randomized, blinded experimental study conducted in the animal laboratory and the animal experimentation surgical center of the Santa Casa de São Paulo. The institutional Animal Research Ethics Committee of UNIFESP and the Santa Casa de São Paulo approved the protocol (approval letter 1476/09). The animal study was carried out in compliance with the recommendations of the Association for Research and Vision in Ophthalmology (ARVO).

\section{Animal selection}

Ten male New Zealand white rabbits weighing 3-4 kg were randomly divided into two groups, with five rabbits in each group (the experimental and control groups). The animals were provided with food and water ad libitum and pertinent veterinary supervision.

\section{EXPERIMENTAL MODEL OF CORNEAL ALKALI BURN}

An experimental model of corneal burn that has already been described in previous studies was used ${ }^{(15,16)}$. This model was modified only with respect to the diameter of the paper disc in order for it to include the total limbal area. A grade IV ocular burn, according to the Roper Hall classification ${ }^{(17,18)}$, was induced in the right eye of all the rabbits.

Under the supervision of a veterinarian, general anesthesia was induced by an intramuscular injection of ketamine hydrochloride (25 mg/kg of weight) associated with $2 \%$ xylazine hydrochloride (4 mg/kg of weight). Appropriate ventilatory support was provided. Corneas were anesthetized using a drop of $1 \%$ proparacaine hydrochloride ophthalmic drops in the animals' right eyes. A corneal alkali burn was then induced by applying a $14 \mathrm{~mm}$ diameter filter paper disc (Whatman filter paper, \# 40) soaked in $1 \mathrm{~N} \mathrm{NaOH}$ (Figure 1). This disc was maintained in contact with the cornea and the limbus for one minute, after which the eyes of the animals were washed with 1.0 cc of $0.9 \% \mathrm{NaCl}$.

Sixty minutes after the injury procedure, $0.1 \%$ riboflavin drops (Ophthalmos ${ }^{\circledR}$, São Paulo, Brazil) were applied every five minutes for thirty minutes to the animals in the experimental group. This step was then followed by irradiation with ultraviolet light (UVA $370 \mathrm{~nm}$, with an irradiance of $3 \mathrm{~mW} / \mathrm{cm}^{2}$ and a surface dose of $5.4 \mathrm{~J} / \mathrm{cm}^{2} ; X$-link, Opto, Brazil) for 30 minutes at a distance of $45 \mathrm{~mm}$ from the right eye, and including the total cornea and limbus area. The epithelium

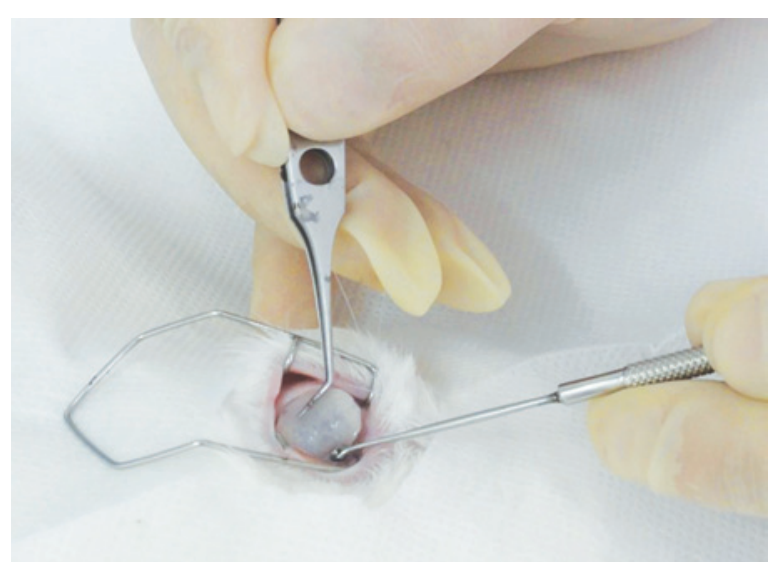

Figure 1. Induction of ocular burns with alkali-immersed filter disks: $14 \mathrm{~mm}$ diameter filter paper discs (Whatman filter paper, \#40) soaked in $1 \mathrm{~N} \mathrm{NaOH}$. was not touched during the procedure. During UVA irradiation, $0.1 \%$ riboflavin drops continued to be applied concomitantly every five minutes. Next, clinical treatment was initiated with the application of a $1 \%$ prednisolone acetate ophthalmic suspension (Pred Fort, Allergan, Guarulhos, SP, Brazil), preservative-free lubricant eye drops (Optive UD, Allergan), and $0.3 \%$ ofloxacin eye drops (Oflox, Allergan). These were all administered three times a day (tid) for the first 15 days (early phase). After this period, the corticosteroid treatment was stopped and only the lubricant eye drops and the antibiotic were maintained for another 15 days (regenerative phase).

The control group ( 5 eyes in 5 rabbits) was submitted to the same clinical treatment described above after the burn had been induced and the eye washed with $1.0 \mathrm{cc}$ of $0.9 \% \mathrm{NaCl}$.

\section{FolLoW-UP AND EXAMINATION OF THE ANIMALS}

The animals underwent a 30 day follow up, with evaluations being conducted by two independent, blinded observers immediately after the burn, and then on days 1, 7, 15, and 30 following the injury. Evaluation of the corneal surface was conducted by external examination and then by biomicroscopy using a hand-held slit lamp (Heine-HSL 100, USA).

Thirty days after the ocular burn, all the rabbits were sacrificed using a $3 \mathrm{ml}$ intramuscular injection of $0.2 \%$ acepromazine, followed 15-20 minutes later by $5 \mathrm{ml}$ intravenous thionembutal and $3 \mathrm{ml}$ intravenous potassium chloride. The corneas were then excised and histological sections were prepared and examined following hematoxylin/eosin ( $\mathrm{HE})$ and trichrome Masson staining for assessing the collagen stroma in the two groups.

\section{Clinical parameters used}

Clinical parameters are described on table $1^{(16,18-20)}$. An example of epithelial defect evaluation can be observed on figure 2 .

\section{Statistical analysis}

Kappa coefficients were calculated to estimate observer agreement for all the clinical variables investigated. Fisher's exact test was used to compare differences between the experimental and control groups. For the continuous variables, means, standard deviations, medians, and ranges were calculated. The Mann-Whitney $U$ test was used to compare the continuous variables between groups, with $\mathrm{p}$ values $<0.05$ being considered statistically significant. The complete statistical analysis was conducted using the STATA statistical software package, version 10 (College Station, Texas, USA).

\section{RESULTS}

There was high agreement between the two independent observers, as shown by the kappa coefficient range of 0.32-1.0.

There was a statistically significant difference between the two groups with respect to the mean size of the corneal epithelial defect at 15 and 30 days after the injury procedure (Table 2). There was also a statistically significant difference in the mean extent of corneal injury (opacity lesion) at day 30 (Table 3).

No statistically significant differences were found between the experimental and control groups with respect to clinical parameters such as conjunctival hyperemia, ocular secretion, corneal neovascularization, ciliary injection, central corneal edema, limbal ischemia, blepharospasm, or symblepharon during the post-injury followup (Table 4).

In the CXL group, histology revealed collagen bridges linking collagen fibers that were arranged in an organized pattern (Figure 3). However, these bridges were absent in the control group (Figure 4). Table 5 shows the presence or absence of bridges in the corneas evaluated. 
Table 1. Grading of clinical parameters evaluated

\begin{tabular}{|c|c|c|c|c|c|}
\hline & Grade 0 & Grade 1 & Grade 2 & Grade 3 & Grade 4 \\
\hline Secretion ${ }^{(18)}$ & Absent & $\begin{array}{c}\text { Traces of secretion in the cul-de-sac } \\
\text { or eyelid margins }\end{array}$ & $\begin{array}{c}\text { Small amount of secretion } \\
\text { visible in the conjunctiva and } \\
\text { on the eyelid margins }\end{array}$ & $\begin{array}{l}\text { Large amount of } \\
\text { secretion, eyeball } \\
\text { is still visible }\end{array}$ & $\begin{array}{c}\text { An excessive amount of } \\
\text { secretion, hampering the } \\
\text { opening of the } \\
\text { palpebral fissure }\end{array}$ \\
\hline Hyperemia and chemosis ${ }^{(18)}$ & Absent & Slight conjunctival injection & $\begin{array}{l}\text { Moderate conjunctival } \\
\text { injection with mild chemosis }\end{array}$ & $\begin{array}{l}\text { Moderate to } \\
\text { intense injection } \\
\text { of vessels, mild } \\
\text { chemosis }\end{array}$ & $\begin{array}{c}\text { Intense injection of vessels, } \\
\text { intense chemosis }\end{array}$ \\
\hline Neovascularization & Absent & $\begin{array}{l}\text { One vessel extending } 0.5 \mathrm{~mm} \\
\text { from the limbus }\end{array}$ & $\begin{array}{c}\text { One or more vessels, with } \\
\text { fewer than five branches, } \\
\text { extending } 0.5 \mathrm{~mm} \text { from the } \\
\text { limbus }\end{array}$ & $\begin{array}{l}\text { Three or more } \\
\text { vessels; or two } \\
\text { vessels, with more } \\
\text { than five branches, } \\
\text { extending } 0.5 \mathrm{~mm} \\
\text { from the limbus }\end{array}$ & \\
\hline Ciliary injection ${ }^{(19,20)}$ & Absent & $<1 \mathrm{~mm}$ & $1-2 \mathrm{~mm}$ & $>2 \mathrm{~mm}$ & \\
\hline Corneal edema ${ }^{(19,20)}$ & Absent & $\begin{array}{l}\text { Present, details of the } \\
\text { iris are visible }\end{array}$ & No details of the iris are visible & $\begin{array}{l}\text { Neither the iris nor } \\
\text { the pupil is visible }\end{array}$ & \\
\hline Limbal ischemia(16) & Absent & $\begin{array}{l}\text { Less than one-third of the } \\
\text { limbus circumference }\end{array}$ & $\begin{array}{l}\text { Between one-third and half of } \\
\text { the limbus circumference }\end{array}$ & $\begin{array}{l}\text { More than half } \\
\text { the limbus } \\
\text { circumference }\end{array}$ & \\
\hline Blepharospasm & Absent & Present & & & \\
\hline Symblepharon & Absent & Present & & & \\
\hline Epithelial defect & \multicolumn{5}{|c|}{$\begin{array}{l}\text { Mean between the largest horizontal and the largest vertical measurements of the fluorescein-stained epithelial defect, } \\
\text { as measured in millimeters using a surgical caliper. (Figure 2) }\end{array}$} \\
\hline Corneal injury & \multicolumn{5}{|c|}{$\begin{array}{r}\text { Mean between the largest horizontal and the largest vertical measurements of the opacity lesion created by the burn, } \\
\text { measured in millimeters using a surgical caliper }\end{array}$} \\
\hline
\end{tabular}
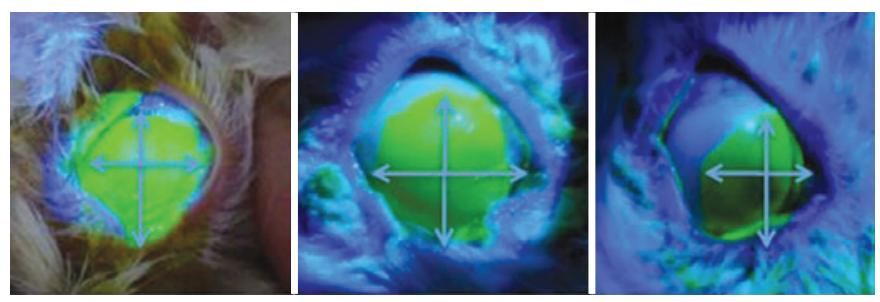

Figure 2. Horizontal and vertical diameters of the epithelial defect in animal \#2, measured 1,15 , and 30 days following surgery: day 1 , range $13-13 \mathrm{~mm}$, mean $13 \mathrm{~mm}$; day 15 , range 8-10 mm, mean $9 \mathrm{~mm}$; day 30, range $5-7 \mathrm{~mm}$, mean $6 \mathrm{~mm}$.

\section{DISCUSSION}

In the present study, we used $14 \mathrm{~mm}$ alkali-immersed filter discs (1 N NaOH) to create severe ocular burns (Roper Hall criteria, grade IV). This methodology was chosen because it has been well described and involves clinically comparable parameters that can be easily measured.

We hypothesized that CXL would allow covalent bonds to be formed between the collagen fibrils, thus promoting thickening of the collagen fibrils through the deposit of structural molecules such as proteoglycans ${ }^{(21)}$, and possibly making the cornea more resistant to the effect of collagenolytic enzymes. In the CXL group, histopathological examinations revealed collagen bridges linking the collagen fibers in the corneal stroma. This may indicate that the collagen fibers in the CXL group were more resistant to collagenolytic enzymes than those in the control group. Furthermore, the arrangement pattern of the stromal collagen fibers was more organized in the CXL group compared to the control group. This may also indicate a greater resistance of the collagen fibers to collagenolytic enzymes in the CXL group, resulting in improved wound healing. Nevertheless, further investigation is required with respect to these collagen bridges and wound healing. Some case reports have also shown the antimicrobial effect of ultraviolet light associated with riboflavin in the treatment of infectious keratitis. The mechanism is presumably either due to the bactericidal effect of ultraviolet light or to the increased resistance of the collagen fibers of the cornea, which prevents the infectious agent from proliferating ${ }^{(12,21,22)}$.

A statistically significant difference was found between the groups regarding the mean extent of the corneal injury on day 30 following the injury ( $p=0.021)$. At this time point the lesion caused by the ocular burn is at a late phase of tissue repair; the effect of collagenolytic enzymes has been largely overcome, and the tissue has undergone regeneration of the fibroblasts, with migration of myofibrils to the site and progressive re-epithelization taking place. The associated effects of the increase in resistance to the collagenases in the first few weeks, and the increase in the rigidity of the corneal tissue due to cross-linking, suggests a better recovery in the CXL group compared to the control group. It should be noted that even considering the statistical significance of our results with respect to the mean extent of the corneal injury, when the absolute data is taken into consideration the difference in the mean size of the lesions is close to $1 \mathrm{~mm}$.

The magnitude of this measurement is imperceptible in clinical practice when considering devastating grade IV burns.

Statistically significant results regarding the mean size of the corneal epithelial defect were also found on post-injury days $15(p=0.008)$ and 30 ( $p=0.008)$. Therefore, we can conclude that the centripetal movement of the corneal epithelial cells that occurs in the regeneration phase of the burned cornea occurred faster in the experimental group compared to the control group. The centripetal movement is associated with an increase in the rigidity of the cornea and the resistance of the tissue to enzymatic degradation through the formation of stronger stroma. This serves as a base for the sliding of the epithelial cells during the recovery phase of the corneal epithelial wound.

Some of the difficulties encountered during this study that merit particular mention refer to the objective measurement of the data obtained from the rabbits, and the manipulation of the animals' eyes 
Table 2. Mean size of the corneal epithelial defect in the rabbits following ocular alkali burn

\begin{tabular}{|c|c|c|c|}
\hline \multirow[b]{2}{*}{ Time post-injury } & \multicolumn{2}{|c|}{$\begin{array}{l}\text { Size of the corneal epithelial defect } \\
(\text { Mean } \pm \text { SD) }(\mathrm{mm})\end{array}$} & \multirow[b]{2}{*}{$p$-value* } \\
\hline & Experimental group & Control group & \\
\hline $1^{\text {st }}$ day & $13.20 \pm 0.20$ & $13.20 \pm 0.20$ & 1.000 \\
\hline $7^{\text {th }}$ day & $9.85 \pm 0.87$ & $10.95 \pm 0.71$ & 0.089 \\
\hline $15^{\text {th }}$ day & $6.40 \pm 0.92$ & $9.10 \pm 0.87$ & 0.008 \\
\hline $30^{\text {th }}$ day & $4.05 \pm 0.94$ & $6.40 \pm 0.65$ & 0.008 \\
\hline
\end{tabular}

Experimental group $=$ cross-linking plus clinical treatment; Control group $=$ only clinical treatment; $P^{*}=$ Mann-Whitney $U$ test, with $p$-values $<0.05$ being considered statistically significant.

Table 3. Mean extent of the corneal injury (opacity lesion) in the rabbits after ocular alkali burn

\begin{tabular}{lccc}
\hline & \multicolumn{2}{c}{$\begin{array}{c}\text { Extent of the corneal injury } \\
\text { (Mean } \pm \text { SD) }(\mathbf{m m})\end{array}$} & \\
\cline { 2 - 3 } Time post-injury & Experimental group & Control group & p-value* \\
\hline $1^{\text {st }}$ day & $13.10 \pm 0.22$ & $13.00 \pm 0.11$ & 0.881 \\
$7^{\text {th }}$ day & $13.05 \pm 0.00$ & $12.95 \pm 0.11$ & 0.317 \\
$15^{\text {th }}$ day & $12.20 \pm 0.44$ & $12.00 \pm 0.58$ & 0.737 \\
$30^{\text {th }}$ day & $10.35 \pm 0.74$ & $11.60 \pm 0.54$ & $\mathbf{0 . 0 2 1}$ \\
\hline
\end{tabular}

Experimental group $=$ cross-linking plus clinical treatment; Control group $=$ only clinical treatment; $\mathrm{P}^{*}=$ Mann-Whitney $U$ test, with $\mathrm{p}$-values $<0.05$ being considered statistically significant.

Table 4. Mann-Whitney U-test $p$-values for the various clinical parameters evaluated at the different time-points following the injury procedure

\begin{tabular}{|c|c|c|c|c|}
\hline \multirow{2}{*}{$\begin{array}{l}\text { Clinical parameters } \\
\text { ( } p \text {-values) }\end{array}$} & \multicolumn{4}{|c|}{ Time post-injury } \\
\hline & $1^{\text {st }}$ day & $7^{\text {th }}$ day & $15^{\text {th }}$ day & $30^{\text {th }}$ day \\
\hline Ocular secretion & 0.206 & 0.444 & 0.444 & 0.444 \\
\hline Conjunctival hyperemia & 0.444 & $\mathrm{n} / \mathrm{c}$ & 1.000 & 0.167 \\
\hline Neovascularization & $\mathrm{n} / \mathrm{c}$ & 0.167 & 0.524 & 0.524 \\
\hline Ciliary injection & 0.444 & 0.167 & 0.444 & 1.000 \\
\hline Edema & 1.000 & 1.000 & 1.000 & 1.000 \\
\hline Limbal ischemia & $n / c$ & $n / c$ & $n / c$ & $n / c$ \\
\hline Blepharospasm & $n / c$ & $n / c$ & $n / c$ & $n / c$ \\
\hline Symblepharon & $\mathrm{n} / \mathrm{c}$ & $\mathrm{n} / \mathrm{c}$ & 0.206 & 0.206 \\
\hline
\end{tabular}

$\mathrm{P}^{*}=$ Mann-Whitney $U$ test, with $\mathrm{p}$-values $<0.05$ being considered statistically significant; $\mathrm{n} / \mathrm{c}=$ not calculated.

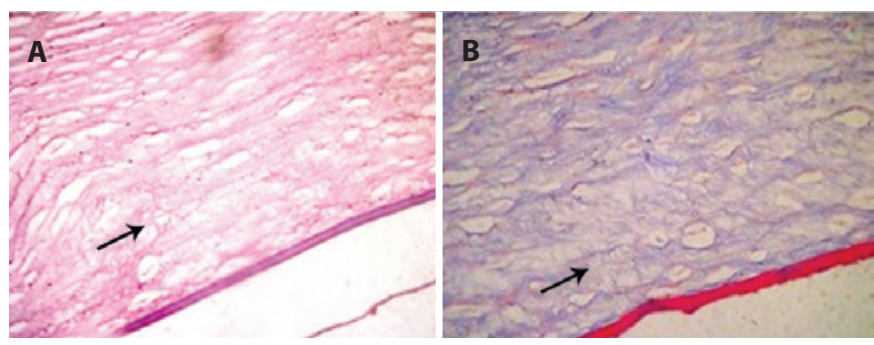

Figure 3. Alkali-burned corneal stroma following 30 days of CXL treatment. Note the organized pattern of collagen bridges (arrow) between the stromal fibers. HE staining (A) and trichrome Masson staining (B).

when using a hand-held slit lamp. Measuring the greatest horizontal and vertical diameters also proved difficult, since although the lesions were circular and symmetrical throughout their extension,
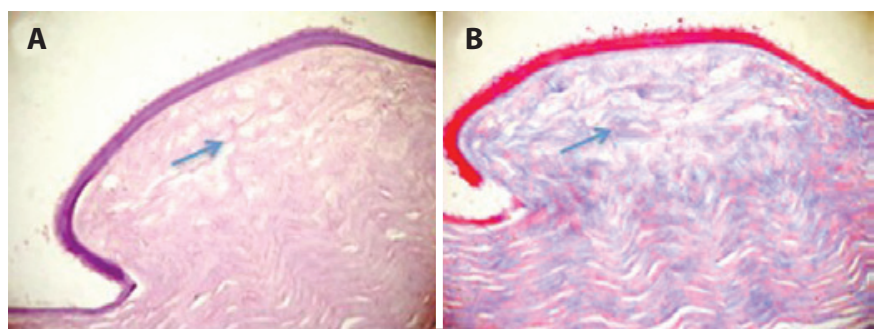

Figure 4. Corneal stroma 30 days after the alkali-burn procedure in the control group. Note the disorganized pattern of collagen fibers and the absence of bridges (arrow) between the stromal fibers. HE staining $(A)$ and trichrome Masson staining (B).

Table 5. Presence or absence of stromal interfibrillar bridges in histological sections of alkali-burned rabbit corneas according to the procedure performed (CXL or none)

\begin{tabular}{ccc}
\hline Animal number & Corneal procedure & Interfibrillar bridges \\
\hline 1 & CXL & Yes \\
2 & CXL & No \\
3 & CXL & Yes \\
4 & CXL & Yes \\
5 & CXL & No \\
6 & Control & No \\
7 & Control & No \\
8 & Control & No \\
9 & Control & No \\
10 & Control & No \\
\hline
\end{tabular}

in some cases there were slight discrepancies in re-epithelialization. This occasionally gave rise to asymmetry in the shape of the healing wound. In addition, the sample size used in this study was small (5 rabbits in the CXL group and 5 in the control group). However, it is important to stress that these numbers were agreed upon following an in-depth discussion with the ethics committee for animal research.

The mechanism underlying the statistically significant differences found at later post-injury time-points remains largely unclear, and we therefore recommend that further studies be conducted to clarify the physiopathogenesis of cross-linking in ocular burns.

In conclusion, these results suggest that the use of CXL may improve the prognosis of acute corneal alkali burns.

\section{REFERENCES}

1. Wagoner MD. Chemical injuries of the eye: current concepts in pathophysiology and therapy. Surv Ophthalmol. 1997;41(4):275-313.

2. Bechara SJ, Garcia IA, Kobinger E, Rodriques CJ, Kara José N, Caldeira JA. [Simultaneous use of acetylcysteine and vitamin $C$ in the therapeutics of cornea burns by alkali]. Arq Bras Oftalmol. 1986;49(4):109-11.

3. Joseph A, Dua HS, King AJ. Failure of amniotic membrane transplantation in the treatment of acute ocular burns. Br J Ophthalmol. 2001;85(9):1065-9.

4. Gomes JA, Romano A, Santos MS, Dua HS. Amniotic membrane use in ophthalmology, Curr Opin Ophthalmol. 2005;16(4):233-40

5. Nishiwaki-Dantas MC, Dantas PE, Reggi JR. Ipsilateral limbal translocation for treatment of partial limbal deficiency secondary to ocular alkali burn. Br J Ophthalmol. 2001;85(9):1031-3.

6. Cypel MC, Goulard DA, Lima FA, Lake JC, Uesugui E, Nishiwaki-Dantas MC, et al. [Subconjunctival injection of autogenous blood in the treatment of ocular alcali burn in rabbits]. Arq Bras Oftalmol. 2004;67(5):801-5.

7. McCall AS, Kraft S, Edelhauser HF, Kidder GW, Lundquist RR, Bradshaw $H E$, et al. Mechanisms of corneal tissue cross-linking in response to treatment with topical riboflavin and long-wavelength ultraviolet radiation (UVA). Invest Ophthalmol Vis Sci. 2010;51(1):129-38.

8. Spoerl E, Mrochen M, Sliney D, Trokel S, Seiler T. Safety of UVA-riboflavin cross-linking of the cornea. Cornea. 2007:26(4):385-9. 
9. Kolli S, Aslanides IM. Safety and efficacy of collagen crosslinking for the treatment of keratoconus. Expert Opin Drug Saf. 2010;9(6):949-57.

10. Schnitzler E, Spörl E, Seiler T. Irradiation of cornea with ultraviolet light and riboflavin administration as a new treatment for erosive corneal processes, preliminary results in four patients. Klin Monbl Augenheilkd. 2000;217(3):190-3.

11. Spoerl E, Wollensak G, Seiler T. Increased resistance of crosslinked cornea against enzymatic digestion. Curr Eye Res. 2004;29(1):35-40.

12. Iseli HP, Thiel MA, Hafezi F, Kampmeier J, Seiler T. Ultraviolet A/riboflavin corneal cross-linking for infectious keratitis associated with corneal melts. Cornea. 2008;27(5):590-4.

13. Hersh PS, Greenstein SA, Fry KL. Corneal collagen crosslinking for keratoconus and corneal ectasia: one-year results. J Cataract Refract Surg. 2011:37(1):149-60.

14. Jankov MR $2^{\text {nd }}$, Hafezi F, Beko M, Ignjatovic Z, Djurovic B, Markovic V, et al. [Corneal cross-linking for the treatment of keratoconus: preliminary results]. Arq Bras Oftalmol. 2008;71(6):813-8

15. Sangwan VS, Akpek EK, Voo I, Zhao T, Pinar V, Yang J, et al. Krill protease effects on wound healing after corneal alkali burn. Cornea. 1999;18(6):707-11.
16. Siganos CS, Frucht-Pery J, Muallem MS, Berenshtein E, Naoumidi I, Ever-Hadani P, et al Topical use of zinc desferrioxamine for corneal alkali injury in a rabbit model. Cornea. 1998;17(2):191-5.

17. Roper-Hall MJ. Thermal and chemical burns. Trans Ophthalmol Soc U K. 1965:85:631-53

18. Santos NC, Sousa LB, Freitas D, Rigueiro MP, Scarpi MJ. [Corneal and conjunctival toxicity of povidone-iodine eye drops]. Arq Bras Oftalmol. 2003;66(3):279-88. Portuguese.

19. Laria C, Alió JL, Ruiz-Moreno JM. Combined non-steroidal therapy in experimenta corneal injury. Ophthalmic Res. 1997;29(3):145-53.

20. Oztürk F, Kurt E, Cerci M, Emiroglu L, Inan U, Türker M, et al. The effect of propolis extract in experimental chemical corneal injury. Ophthalmic Res. 2000;32(1):13-8.

21. Al-Sabai N, Koppen C, Tassignon MJ. UVA/riboflavin crosslinking as treatment for corneal melting. Bull Soc Belge Ophtalmol. 2010(315):13-7.

22. Makdoumi K, Mortensen J, Sorkhabi O, Malmvall BE, Crafoord S. UVA-riboflavin photochemical therapy of bacterial keratitis: a pilot study. Graefes Arch Clin Exp Ophthalmol. 2012;250(1):95-102.

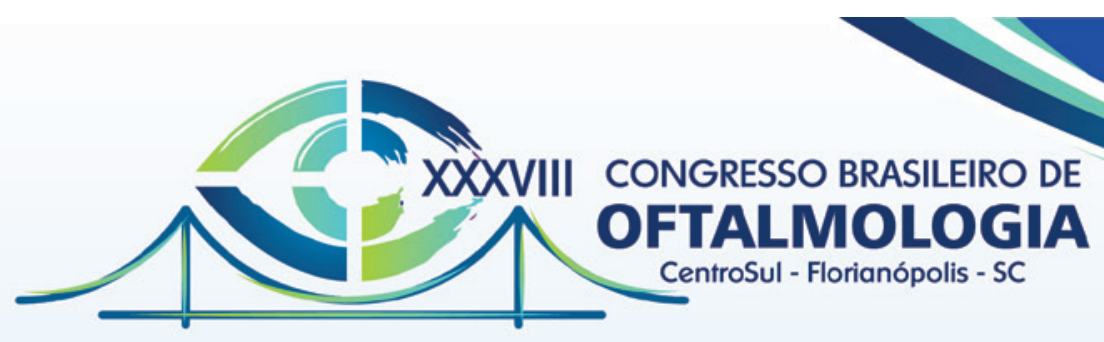

2 a 5 de setembro de 2015

\section{Floripa te espera em 2015 para o maior evento da oftalmologia do Brasil.}

A bela capital catarinense será mais uma vez palco deste que é considerado o maior e mais importante evento da oftalmologia no Brasil. Os maiores nomes nacionais e internacionais estarão presentes.

Palestras, Stands, Exposição de Trabalhos Científicos e muito mais.

Esperamos por você!

REALIZAGÁOO

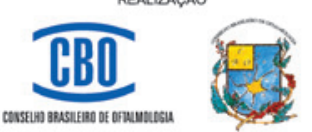

APOIO

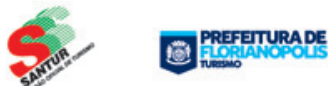

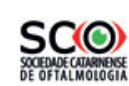

Floripa2015 cbo2015.com.br

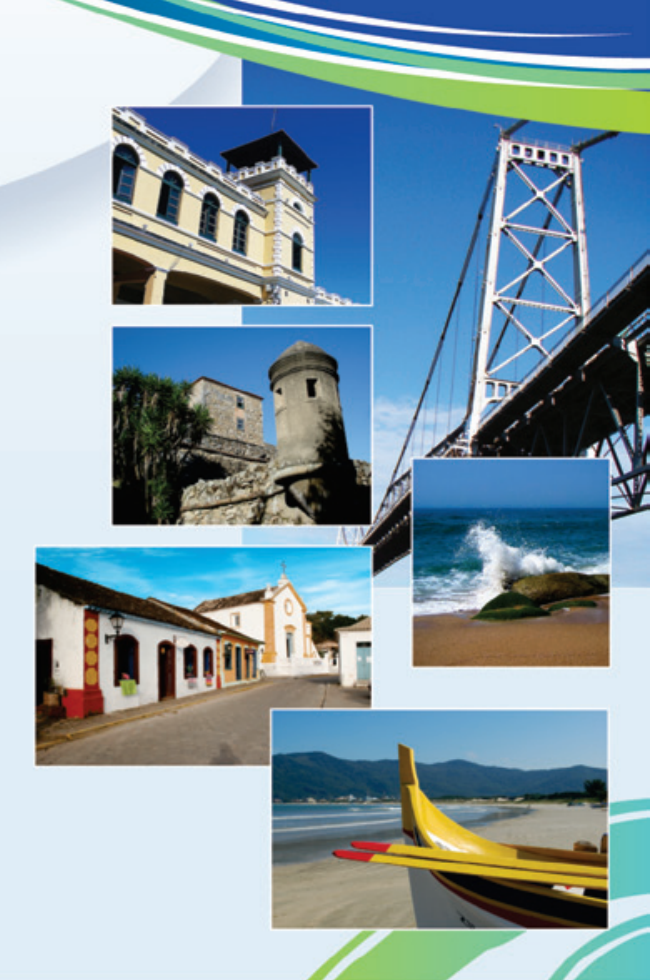

AGENCIADE
TURISMO OFICIAL

LOCAL

ORGANIZAGÁO

(1)

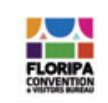

